Original Article

\title{
Anti-dermatophyte activity of the aqueous extracts of Thai medicinal plants
}

\author{
Atividade antidermatófita dos extratos aquosos de plantas medicinais tailandesas \\ S. Chaiwaree ${ }^{\mathrm{a}}$ (D), Y. Pongpaibul ${ }^{\mathrm{a}}$ (D) and P. Thammasit ${ }^{\mathrm{b} *}$ (D) \\ apayap University, Faculty of Pharmacy, Department of Pharmaceutical Technology and Biotechnology, Chiang Mai, Thailand \\ ${ }^{\mathrm{b} C}$ Chiang Mai University, Faculty of Medicine, Department of Microbiology, Chiang Mai, Thailand
}

\begin{abstract}
Medicinal plants have long been prescribed in Thailand for centuries. Different constituents of extracts have been used for treating of various infectious diseases. However, there is even less information available regarding the use in fungal skin infection. In order to assess traditional Thai claims about the therapeutic potential, this study is focused on exploring the anti-dermatophyte property of the plants that are currently used as traditional medicines. The potential of four different plant species were selected for investigate in vitro anti-dermatophyte activity. Ethanolic extracts of Chromolaena odorata (L.), Ageratina adenophora (Spreng.), Eclipta prostrate (Linn.), and Acorus calamus (L.). were analysed for their total phenolic content as well as total flavonoid content and were then subjected to test of their anti-dermatophyte properties using agar well diffusion method. Qualitative flavonoids and phenolics analysis of the extracts showed their biologically active constituents. Among the species examined, the result indicated that most of the extracts demonstrated anti-dermatophyte activity. In particular, A. calamus showed the highest efficacy against test organisms. The experiment confirmed the chemical constituents and efficacy of some selected plants and provides a scientific confirmation of the use of Thai plants in traditional medicine for fungal skin infections.
\end{abstract}

Keywords: Thai medicinal plant extracts, anti-fungal activity, anti-dermatophyte activity, dermatophytes, Trichophyton spp.

\begin{abstract}
Resumo
As plantas medicinais são prescritas há muito tempo na Tailândia, há séculos. Diferentes constituintes de extratos têm sido usados para o tratamento de várias doenças infecciosas. No entanto, existem ainda menos informações disponíveis sobre o uso em infecções fúngicas da pele. A fim de avaliar as alegações tradicionais tailandesas sobre o potencial terapêutico, este estudo está focado em explorar a propriedade antidermatófita das plantas que são usadas atualmente como medicamentos tradicionais. O potencial de quatro espécies de plantas diferentes foi selecionado para investigar a atividade antidermatófita in vitro. Extratos etanólicos de Chromolaena odorata (L.), Ageratina adenophora (Spreng.), Eclipta prostrate (Linn.) e Acorus calamus (L.) foram analisados quanto ao seu conteúdo fenólico total, bem como ao conteúdo de flavonoides totais. E então submetidos ao teste de suas propriedades antidermatófitas usando o método de difusão em ágar bem. A análise qualitativa de flavonoides e fenólicos dos extratos mostrou seus constituintes biologicamente ativos. Entre as espécies examinadas, o resultado indicou que a maioria dos extratos demonstrou atividade antidermatófita. Em particular, A. calamus mostrou a maior eficácia contra organismos de teste. $O$ experimento confirmou os constituintes químicos e a eficácia de algumas plantas selecionadas e fornece uma confirmação científica do uso de plantas tailandesas na medicina tradicional para infecções fúngicas da pele.
\end{abstract}

Palavras-chave: extratos de plantas medicinais tailandesas, atividade antifúngica, atividade antidermatófita, dermatófitos, Trichophyton spp.

\section{Introduction}

Dermatophytes are keratinophilic fungi that is a unique group of fungi that infect keratinous tissue (skin, hair, and nails) of a living human hosts and other animals to produce an infection (Havlickova et al., 2008). This closely related group of organisms that consist of three main

genera including Trichophyton spp. (T. mentagrophytes, $T$. rubrum, and T. verrucosum), Microsporum spp. (M. canis and M. gypseum), and Epidermophyton. Among the dermatophytes, T. mentagrophytes and T. rubrum are two of the most frequently isolated dermatophytes that causes

*e-mail: patcharin.th@cmu.ac.th

Received: July 15, 2021 - Accepted: December 8, 2021

This is an Open Access article distributed under the terms of the Creative Commons Attribution License, which permits unrestricted use, distribution, and reproduction in any medium, provided the original work is properly cited. 
dermatophytosis worldwide and the increased number of immunocompromised states such as AIDS, diabetes mellitus, cancer and organ transplantation has given these infections more prominence (Fernandez-Torres et al., 2001; Zhan and Liu 2017; Frías-De-León et al., 2020). T. mentagrophytes is a zoophilic dermatophyte of wild and domestic rodents that often attacks humans and may also survive saprophytically in the soil (Terragni et al., 1993). It is a contagious fungus which primarily causes dermatophytosis such as tinea pedis, tinea unguium, tinea corporis, and tinea capitis. It distributes all over the world, especially in moist and carbon-rich environments. While T. rubrum is the most prevalent dermatophyte isolated from humans with accounting for about $80 \%$ of dermatomycoses that affect keratinized tissues such as skin, hair, and nails (Gupta and Nakrieko, 2015). It is a worldwide agent responsible for chronic cases of dermatophytosis which have high rates of resistance to anti-fungal drugs (Pereira et al., 2013). Moreover, infections due to T. rubrum are often associated with frequent relapses following cessation of anti-fungal therapy (Mukherjee et al., 2003).

Common therapeutic strategies for dermatophytosis are based on the use of topical and systemic anti-fungal agents. The present line of treatment includes tolnaftate, terbinafine hydrochloride and imidazoles such as ketoconazole, miconazole nitrate and clotrimazole (Singh et al., 2014). Despite an increasing number of safe and highly effective agents available for the treatment of dermatophytosis, there are reports suggesting possible resistance of dermatophytes to anti-fungal agents (Aktas et al., 2014). Furthermore, fungal infections need long-term therapy involving several weeks (Loo, 2006). However, the patient discontinues the application, due to cost factor, resulting in the recurrence of the disease (Weinstein and Berman, 2002). Therefore, there exists a clear demand for additional anti-fungals with therapeutic potential. Hence, herbal plant products that inhibit their growth without harming the host represent potential therapeutic agent. This study introduced the Thai herbal plants in an attempt to demonstrate their antidermatophytic activity against human fungal disorders caused by dermatophytes.

Traditional Thai herbal plants are one of the most valuable heritages from Thai ancestors. Thai herbal plants have been a vital source of both curative and preventive medical therapy preparations for human beings, which also has been used for the extraction of important bioactive compounds. Even though the increasing of modern medicine use, Thai traditional medicine is still widely used as essential resources of phytomedicines and nutraceuticals which could provide a variety of beneficial effects on human health. In particular, extreme variations in the relevant metabolites in traditional Thai herbal plants can pose challenges regarding safety and efficacy during the conduct of a clinical research (Urumarudappa et al., 2019). Nowadays, Thai herbal plants are widely accepted in alternative medicine for treatment the diseases including various infectious diseases. Herbal plant products are gaining popularity each day due to their safety and availability at an affordable price. In this study, we investigated the anti-fungal activity, against dermatophytes fungi that cause cutaneous infections, of 4 Thai-herbal plants collected in Northern Thailand and used in traditional medicines namely: Chromolaena odorata (L.),Ageratina adenophora (Spreng.), Eclipta prostrate (Linn.), Acorus calamus (L.). Some of these species, antimicrobial activities are reported in the literature. These Thai herbal plants extracts are considered as non-phytotoxic compounds and have anti-microbials properties. They can be used as a Thai natural therapy to inhibit fungal pathogens causing superficial infections. However, there is only limited information in the literature on the antidermatophytic activity toward human dermatophyte pathogens. Thus, it is necessary to increase the number of studies on the potential activity of Thai herbs from Northern Thailand against pathogenic fungi.

The aim of this study was to investigate the antidermatophyte effects of Northern Thailand plants. The four investigated species were selected because they are the most abundant and are exclusively distributed in the wild around the highlands of Northern Thailand. Therefore, in the present study, we have initiated studies on the biological function of four medicinal plant species against T. mentagrophytes and T. rubrum.

\section{Materials and Methods}

\subsection{Preparation}

\subsubsection{Plant collection}

Plant materials were collected from various locations in Northern Thailand. Chromolaena odorata (L.) was collected from Li District, Lamphun, Thailand. Ageratina adenophora (Spreng.) was collected from the wild around San Pa Kia highland agricultural research station, Chiang Dao district, Chiang Mai, Thailand. Eclipta prostrate (Linn.) was collected from the wild around Ban Huai Pong Pattana highland agricultural research station, Chai Prakarn district, Chiang Mai, Thailand. Acorus calamus (L.) was collected from the wild around Baan Fa Suay highland agricultural research station, Chiang Dao district, Chiang Mai, Thailand.

\subsubsection{Ethanol (EtOH) extraction procedure}

All plant material was washed with water and air dried under shade and further dried in the air-drying oven at $50^{\circ} \mathrm{C}$ for $8 \mathrm{~h}$, then ground to a fine powder using a laboratory scale mill. One hundred grams powder was macerated for $48 \mathrm{~h}$ in $400 \mathrm{~mL}$ of $95 \%$ ethanol for $C$. odorata and $A$. adenophora and $1,500 \mathrm{~mL}$ of $95 \%$ ethanol for $A$. calamus and $E$. prostrate. Each solvent extraction was repeated 3 times and the extracts were further filtered through qualitative filter paper and the solvent was then removed with a rotary evaporator, and stored at $4^{\circ} \mathrm{C}$ until tested and analysed. The extracts were re-dissolved in dimethyl sulfoxide (DMSO) at the concentration of $5 \%$.

\subsection{In vitro assays}

\subsubsection{Total phenolic compounds determination}

The total phenolic content of all extracts was determined by Folin-Ciocalteu's colorimetric assay. The ethanolic 
solution of each extract was mixed with $50 \%$ of FolinCiocalteu reagent (Merck, NY, USA) for $5 \mathrm{~min}$. Sodium carbonate (5\%) was added and further incubated for $1 \mathrm{~h}$. The absorbance of the reaction was measured at wavelength $725 \mathrm{~nm}$. Total phenolic content was calculated from the Gallic acid standard curve and represented as milligram Gallic acid equivalent per gram extract ( $\mathrm{mg}$ GAE/g extract) (Ghasemi et al., 2009).

\subsubsection{Total flavonoids determination}

The total flavonoid content of all extracts was determined. Each extract in ethanol was mixed with $10 \%$ of aluminium chloride and $1 \mathrm{M}$ potassium acetate. After incubation at room temperature for $30 \mathrm{~min}$, the absorbance of the reaction was measured at a wavelength of $415 \mathrm{~nm}$. Total flavonoid content was calculated from the Quercetin (Merck, NY, USA) standard curve and represented as milligram Quercetin equivalent per gram of extract ( $\mathrm{mg}$ QAE/g extract) (Ghasemi et al., 2009).

\subsection{Microbial testing}

\subsubsection{Fungal strains}

Trichophyton mentagrophytes strain MMC61T11-1 and T. rubrum strain MMC46T12-1 were cultured on Mycosel agar (Sabouraud's dextrose agar supplemented with chloramphenicol and cycloheximide), then incubated at $27^{\circ} \mathrm{C}$ for $14-21$ days. For preparation of spore suspensions, spores were harvested from fresh slants cultured, by adding $10 \mathrm{ml}$ of $0.1 \%$ sterile non-ionic surfactant $(0.01 \%$ of NSSTween 20) to the culture slant. The slant was vortexed for $5 \mathrm{~min}$ and the resulting suspension was filtered through four layers of sterile gauze. The filtered spore suspension was enumerated for spore concentration at $10^{7} \mathrm{SFU} / \mathrm{mL}$.

\subsubsection{Agar-well diffusion method}

All plant extracts were screened, using the agar-well diffusion method (Rios et al., 1988). A 5\% (w/v) test solution of each extract was prepared in DMSO or PEG 400. Standard drug $0.1 \% \mathrm{w} / \mathrm{v}$ Ketoconazole was used as positive control as well as $50 \%$ of DMSO, and $50 \%$ of PEG 400 were used as negative controls. Malt yeast agar (MYA) was used as a culture media and a hole with a diameter of $8 \mathrm{~mm}$ was punched aseptically with a sterile cork borer. Dermatophytes were then inoculated by adding $1 \mathrm{~mL}$ of $10^{7} \mathrm{SFU} / \mathrm{mL}$ into MYA. Extract solution at concentration of $2.5 \%(100 \mu \mathrm{L})$ and controls were dropped in 8 -mm-diameter well. Plates were incubated at $25^{\circ} \mathrm{C}$ for 5-7 days. The diameter of the inhibition zone around each well was measured and recorded. Anti-fungal activity was expressed as the ratio of the average of inhibition zones produced by the extract under test and the average of inhibition zones caused by the positive controls. Each test was performed in triplicate.

\subsubsection{Minimum inhibitory concentration (MIC)}

The minimum inhibitory concentration (MIC) was determined using the microplate method (Eloff, 1998). Test solution of each extract solution was serially 2 -fold diluted (2.5\% to $0.625 \%$ ) with RPMI 1640 with MOPS $0.165 \mathrm{M}$ medium $(100 \mu \mathrm{L})$, and $100 \mu \mathrm{L}$ of $5 \times 10^{4} \mathrm{SFU} /$ $\mathrm{mL}$ of dermatophytes was added to 96-well microplate. In addition, medium alone, extract solution alone, and cell growth control were used as controls. The microplates were incubated overnight at $28^{\circ} \mathrm{C}$ for $48 \mathrm{~h}$. MIC was defined as the lowest anti-fungal concentration resulting in $80 \%$ inhibition of growth as determined visually compared with growth control.

\subsubsection{Minimal fungicidal concentration (MFC)}

To determine the minimum fungicidal concentration (MFC), broth suspension was taken $20 \mu \mathrm{L}$ from the microplate wells and cultured on solid MYA. Plates were then incubated overnight at $28^{\circ} \mathrm{C}$ for 5 days. When the microorganism did not grow, the sample was considered fungicidal.

\section{Results and Discussion}

\subsection{Plant materials and extraction yield}

Concurrent with the era of developed resistance against synthetic antibiotics, there has been a corresponding decrease in anti-microbial discovery. This has directed researchers toward alternative therapies, especially traditional plant-based medicines. Plants belonging to different families, from the region of Northern Thailand were screened for their anti-fungal activity against dermatophytes. Total 4 plants were selected and extracted with ethanol, a common solvent which most efficient for extracting herbal/plants. Table 1 represented the details of plants studied, in terms of their botanical name and family. Plant's extract (crude extract) was prepared in triplicates and the yield was calculated as a percentage of dry plant weight as shown in Table 2 . The extract of $100 \mathrm{~g}$ of dried plant materials with ethanol yielded plant extract residues ranged from 4.48 to $15.50 \%$. The highest yield of plant extract was obtained from E. prostrate

Table 1. Plants studied for anti-dermatophyte activity.

\begin{tabular}{ccc}
\hline Plant species & Family & Part used \\
\hline Chromolaena odorata (L.) & Chromolaena & Leaves \\
Ageratina adenophora (Spreng.) & Asteraceae & Leaves \\
Eclipta prostrate (Linn.) & Asteraceae & Leaves \\
Acorus calamus (L.) & Acoraceae & Stem and leaves \\
\hline
\end{tabular}


(Linn.) followed by C. odorata (L.), A. calamus (L.), and A. adenophora (Spreng.), respectively. Each crude plant extract was dissolved in dimethyl sulfoxide (DMSO) and prepared at 5\% concentration as shown in Figure 1 for anti-fungal testing.

\subsection{Total phenolic and total flavonoid contents}

The phenolic and flavonoid contents of four plant extracts were determined and values are shown in Table 3. The crude ethanolic extract of all plants was found containing significant amount of phenols and flavonoids as demonstrated by its total phenolic and flavonoid contents. The data showed that the highest phenolic total was obtained from the extract of $A$. calamus (L.) with respective value of $56.73 \pm 1.82 \mathrm{mg}$ gallic acid equivalents/g extract (mg GAE/g extract) and the highest flavonoid total was obtained from $A$. adenophora (Spreng.) with respective value of $16.48 \pm 0.95 \mathrm{mg}$ quercetin equivalents/g extract (mg QAE/g extract).

Table 2. Extraction yields of the different types of plant.

\begin{tabular}{cc}
\hline Plant species & Extraction yield (\%) \\
\hline Chromolaena odorata (L.) & $8.2 \pm 0.13$ \\
Ageratina adenophora (Spreng.) & $4.48 \pm 0.18$ \\
Eclipta prostrate (Linn.) & $18.50 \pm 0.20$ \\
Acorus calamus (L.) & $5.15 \pm 0.15$ \\
\hline
\end{tabular}

\subsection{Anti-dermatophyte fungi of plant extracts}

Prepared extracts were tested against the dermatophyte species, T. mentagrophytes and T. rubrum. Out of the 4 plants tested, three extracts were active against the tested species. The activity data is listed in Table 4; which shows the plant extracts activity in terms of diameter of zone of inhibition values against the tested species of dermatophyte fungi. The susceptibility profiles between T. mentagrophytes and T. rubrum for each evaluated extract showed closely similar values in the inhibition zone diameters. A. calamus (L.) was the most active with the inhibition zone diameters of greater than $20 \mathrm{~mm}$ followed by C. odorata (L.) and $A$. adenophora (Spreng.). By contrast, the growth of these organisms was not inhibited by any of the E. prostrate (Linn.) extracts, as there were no inhibition zones observed. This suggests that the active biomolecule of $A$. calamus (L.), C. odorata (L.), and A. adenophora (Spreng.) is soluble in hydroalcoholic solvent and has a different activity towards dermatophyte fungi.

Considering the minimal inhibitory concentration (MIC) and minimum fungicidal concentration (MFC) values of active plant extracts, the fungistatic and fungicidal activities are showed in Table 5. All three extracts were fungicidal towards dermatophytes tested, MFC values were found to be higher than the MIC values. As shown in Figure 2, ethanol extracts of A. calamus (L.), C. odorata (L.), and $A$. adenophora (Spreng.) had an equal MIC value $(0.04 \mathrm{mg} / \mathrm{mL})$ against $T$. mentagrophytes, while the MICs in the range of 0.0025 to $0.02 \mathrm{mg} / \mathrm{mL}$ observed in T. rubrum. The extract of $A$. adenophora (Spreng.) had the lowest MIC

Table 3. Total phenolic and flavonoid compound contents in the extracts.

\begin{tabular}{ccc}
\hline Plant species & $\begin{array}{c}\text { Total phenolic compound content } \\
\text { (mg GAE/g extract) }\end{array}$ & $\begin{array}{c}\text { Total flavonoid compound content } \\
\text { (mg QAE/g extract) }\end{array}$ \\
\hline Chromolaena odorata (L.) & $30.80 \pm 2.44$ & $3.74 \pm 1.63$ \\
Ageratina adenophora (Spreng.) & $36.32 \pm 1.21$ & $16.48 \pm 0.95$ \\
Eclipta prostrate (Linn.) & $9.64 \pm 1.29$ & $7.68 \pm 1.25$ \\
Acorus calamus (L.) & $56.73 \pm 1.82$ & $15.78 \pm 1.42$ \\
\hline
\end{tabular}

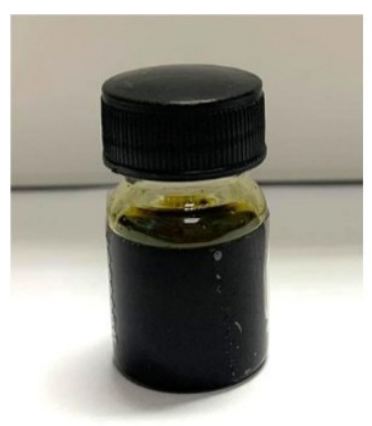

Chromolaena odorata (L.)

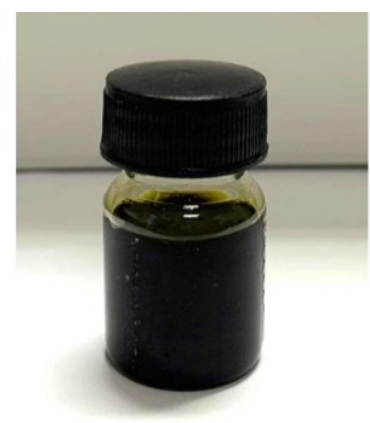

Ageratina adenophora (Spreng.)

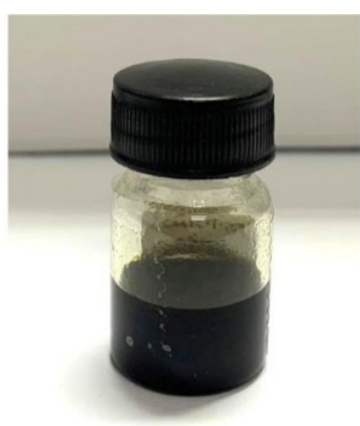

Eclipta prostrate (Linn.)

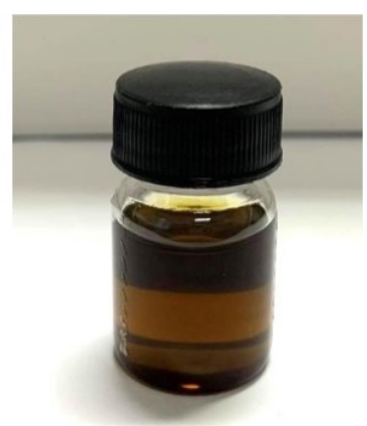

Acorus calamus

(L.)

Figure 1. Ethanolic plant extracts in dimethyl sulfoxide solvent. 
Table 4. Activity profile of active plant extracts against dermatophyte fungi by agar-well diffusion method.

\begin{tabular}{ccc}
\hline Plant extracts & \multicolumn{2}{c}{ Diameter of inhibition zone (mm) } \\
\cline { 2 - 3 } Chromolaena odorata (L.) & T. mentagrophytes & T. rubrum \\
\hline Ageratina adenophora (Spreng.) & ++ & ++ \\
Eclipta prostrate (Linn.) & ++ & - \\
Acorus calamus (L.) & +++ & ++ \\
DMSO control & - & + \\
$0.1 \%$ w/v Ketoconazole & +++ & ++ \\
\hline
\end{tabular}

Notes: Inhibitory zone diameter: +, <10 mm; ++, 10-20 mm; +++, >20 mm; and -, not detected.

Table 5. MIC and MFC values (\%v/v) of active plant extracts against dermatophyte fungi.

\begin{tabular}{ccccc}
\hline \multirow{2}{*}{ Plant extracts } & \multicolumn{2}{c}{ T. mentagrophytes } & \multicolumn{2}{c}{ T. rubrum } \\
\cline { 2 - 5 } & MIC & MFC & MIC & MFC \\
\hline Chromolaena odorata (L.) & 0.04 & 0.32 & 0.02 & 0.08 \\
Ageratina adenophora (Spreng.) & 0.04 & $>0.64$ & $<0.0025$ & $>0.02$ \\
Acorus calamus (L.) & 0.04 & $>0.64$ & 0.02 & 0.08 \\
\hline
\end{tabular}

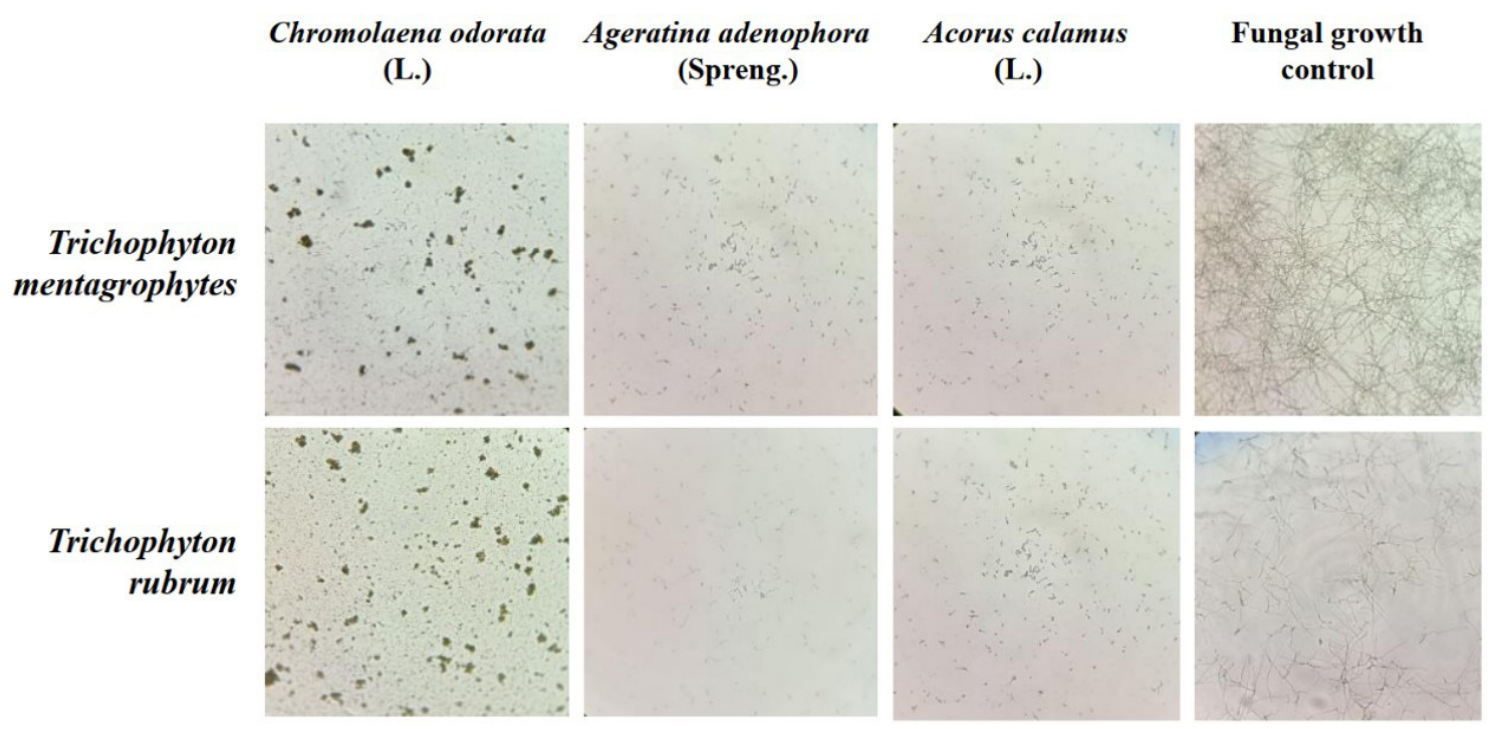

Figure 2. Bright-field microscopy images demonstrating the effect of plant extracts against T. mentagrophytes and T. rubrum at MIC values.

$(<0.0025 \mathrm{mg} / \mathrm{mL})$ towards T. rubrum. Fungicidal action is also reported in Table 5, MFC values were either four times or more eight times higher than those of the corresponding MIC. The tested organisms were sensitive to the reference drug Ketoconazole (data not shown).

The previous studies have revealed the most of Chromolaena genus contains the flavonoids group. One of species from this genus, $C$. odorata, has been reported to demonstrate the phytochemical properties of leaves extract which presence of secondary metabolite compounds such as coumarins, flavonoids, tannins, and sterols. A previous study also reported that the isolation of $C$. odorata $\mathrm{L}$. obtained flavonoid compounds (Pisutthanan et al., 2006). Furthermore, $C$. odorata has been reported to exhibit antibacterial, anti-protozoal, anti-fungal, anti-hypertensive, anti-inflammatory, immunomodulatory and anti-cancer effects (Vijayaraghavan et al., 2017). Our results are in concordance with the study in the $C$. odorata extracts from Cameroon. The data showed the inhibition of fungal growth against Cryptococcus neoformans, Microsporum gypseum, T. mentagrophytes and T. rubrum with a MIC range from 62.5 to $500 \mu \mathrm{g} / \mathrm{mL}$ (Ngono Ngane et al., 2006). A. adenophora [Eupatorium adenophorum (Spreng.)] is a plant rich in terpenes and phenolic compounds (flavonoids, 
phenylpropanoids, and coumarins), and some sterols as well as a few nitrogen-containing natural products have also been reported (He et al., 2008). Studies have shown that Eupatorium and its active principles possess a wide range of pharmacological activities such as cytotoxic, anti-bacterial, anti-inflammatory, as well as anti-fungal activities (Zhang et al., 2008). Furthermore, the chemical constituents of the extracts from A. calamus (L.) have been reported previously. Studies on chemical composition of Acorus spp. have revealed that the phenylpropanoid $\alpha$ - and $\beta$-asarone are the major bioactive compounds and has been shown to have biological functions including antimicrobial activity (McGaw et al., 2000; Kim et al., 2011). Moreover, phenolics and flavonoids are recognised for their multiple biological effects including anti-oxidant and anti-microbial activities (Kim et al., 2011).

On the other hand, the lowest flavonoid and phenolic values in this study was recorded in the extract of E. prostrate (Linn.). These showed relatively poor anti-dermatophytes activity. It has been noted that anti-microbial efficacy of the plant extracts is correlated with their phenolic and flavonoid contents (Mahboubi et al., 2015). Thus, taken together, these studies suggest that the total phenolic and flavonoid contents contribute to the anti-microbial activity of these plants. Out of this suggestion, we would note that the anti-microbial activities of the phenolic compounds are associated to the ability to bind extracellular and soluble proteins, thus enabling complexation with bacterial cell walls (Puupponen-Pimiä et al., 2001). It is reasonable to suggest that flavonoid and phenolic contents in plant extracts may have an effect on dermatophyte fungi through the interference of the cell wall integrity.

\section{Conclusion}

Taken together, ethanol extracts from the studied plants exhibited a potent activity against dermatophyte fungi, T. mentagrophytes and T. rubrum which is associated with the level of total phenolic and flavonoid compound contents. These results suggest that the ethanol extracts of C. odorata (L.), A. adenophora (Spreng.), and A. calamus (L.) could be made available for product development for the prevention of superficial skin infections and related disorders. For the first time, this paper shows evidences of anti-fungal activity of different highland plants extracts used as traditional medicines in Northern Thailand. This study could represent the promising candidates for further pharmacological and clinical studies in the developing formulations of new natural anti-fungal agents.

\section{Acknowledgements}

This work was supported by CMU Junior Research Fellowship Program and the Highland Research and Development Institute (Public Organization).

\section{References}

AKTAS, A.E., YIGIT, N., AKTAS, A. and GOZUBUYUK, S.G., 2014. Investigation of In Vitro activity of five antifungal drugs against dermatophytes species isolated from clinical samples using the E-test method. The Eurasian Journal of Medicine, vol. 46, no. 1, pp. 26-31. http://dx.doi.org/10.5152/eajm.2014.05. PMid:25610290.

ELOFF, J.N., 1998. A sensitive and quick microplate method to determine the minimal inhibitory concentration of plant extracts for bacteria. Planta Medica, vol. 64, no. 8, pp. 711-713. http://dx.doi.org/10.1055/s-2006-957563. PMid:9933989.

FERNÁNDEZ-TORRES, B., CARRILLO, A.J., MARTIN, E., DEL PALACIO, A., MOORE, M.K., VALVERDE, A., SERRANO, M. and GUARRO, J., 2001. In vitro activities of 10 antifungal drugs against 508 dermatophyte strains. Antimicrobial Agents and Chemotherapy, vol. 45, no. 9, pp. 2524-2528. http://dx.doi.org/10.1128/ AAC.45.9.2524-2528.2001. PMid:11502524.

FRÍAS-DE-LEÓN, M.G., MARTINEZ-HERRERA, E., ATOCHE-DIEGUEZ, C.E., CESPON, J.L.G., URIBE, B., ARENAS, R. and RODRIGUEZCERDEIRA, C., 2020. Molecular identification of isolates of the Trichophyton mentagrophytes complex. International Journal of Medical Sciences, vol. 17, no. 1, pp. 45-52. http://dx.doi. org/10.7150/ijms.35173. PMid:31929737.

GHASEMI, K., GHASEMI, Y. and EBRAHIMZADEH, M.A., 2009. Antioxidant activity, phenol and flavonoid contents of 13 citrus species peels and tissues. Pakistan Journal of Pharmaceutical Sciences, vol. 22, no. 3, pp. 277-281. PMid:19553174.

GUPTA, A.K. and NAKRIEKO, K.A., 2015. Trichophyton rubrum DNA strain switching increases in patients with onychomycosis failing antifungal treatments. British Journal of Dermatology, vol. 172, no. 1, pp. 74-80. http://dx.doi.org/10.1111/bjd.13165. PMid:24903451.

HAVLICKOVA, B., CZAIKA, V.A. and FRIEDRICH, M., 2008. Epidemiological trends in skin mycoses worldwide. Mycoses, vol. 51, suppl. 4, pp. 2-15. http://dx.doi.org/10.1111/j.14390507.2008.01606.x. PMid:18783559.

HE, L., HOU, J., GAN, M., SHI, J., CHANTRAPROMMA, S., FUN, H.K., WILLIAMS, I.D. and SUNG, H.H., 2008. Cadinane sesquiterpenes from the leaves of Eupatorium adenophorum. Journal of Natural Products, vol. 71, no. 8, pp. 1485-1488. http://dx.doi.org/10.1021/ np800242w. PMid:18620454.

KIM, W.J., HWANG, K.H., PARK, D.G., KIM, T.J., KIM, D.W., CHOI, D.K., MOON, W.K. and LEE, K.H., 2011. Major constituents and antimicrobial activity of Korean herb Acorus calamus. Natural Product Research, vol. 25, no. 13, pp. 1278-1281. http://dx.doi. org/10.1080/14786419.2010.513333. PMid:21707379.

LOO, D.S., 2006. Systemic antifungal agents: an update of established and new therapies. Advances in Dermatology, vol. 22, pp. 101-124. http://dx.doi.org/10.1016/j.yadr.2006.07.001. PMid:17249298.

MAHBOUBI, A., ASGARPANAH, J., SADAGHIYANI, P.N. and FAIZI, M., 2015. Total phenolic and flavonoid content and antibacterial activity of Punica granatum L. var. pleniflora flowers (Golnar) against bacterial strains causing foodborne diseases. BMC Complementary and Alternative Medicine, vol. 15, no. 1, pp. 366. http://dx.doi.org/10.1186/s12906-015-0887-x. PMid:26470879.

MCGAW, L.J., JAGER, A.K. and VAN STADEN, J., 2000. Antibacterial, anthelmintic and anti-amoebic activity in South African medicinal plants. Journal of Ethnopharmacology, vol. 72, no. 1-2, pp. 247-263. http://dx.doi.org/10.1016/S0378-8741(00)002695. PMid:10967478.

MUKHERJEE, P.K., LEIDICH, S.D., ISHAM, N., LEITNER, I., RYDER, N.S. and GHANNOUM, M.A., 2003. Clinical Trichophyton rubrum strain exhibiting primary resistance to terbinafine. Antimicrobial Agents and Chemotherapy, vol. 47, no. 1, pp. 82-86. http://dx.doi. org/10.1128/AAC.47.1.82-86.2003. PMid:12499173.

NGONO NGANE, A., EBELLE ETAME, R., NDIFOR, F., BIYITI, L., AMVAM ZOLLO, P.H. and BOUCHET, P., 2006. Antifungal activity 
of Chromolaena odorata (L.) King \& Robinson(Asteraceae) of cameroon. Chemotherapy, vol. 52, no. 2, pp. 103-106. http:// dx.doi.org/10.1159/000092373. PMid:16567942.

PEREIRA, F.O., MENDES, J.M. and LIMA, E.O., 2013. Investigation on mechanism of antifungal activity of eugenol against Trichophyton rubrum. Medical Mycology, vol. 51, no. 5, pp. 507-513. http:// dx.doi.org/10.3109/13693786.2012.742966. PMid:23181601.

PISUTTHANAN, N., LIAWRUANGRATH, B., LIAWRUANGRATH, S. and BREMNER, J.B., 2006. A new flavonoid from Chromolaena odorata. Natural Product Research, vol. 20, no. 13, pp. 1192-1198. http://dx.doi.org/10.1080/14786410600899050. PMid:17127508.

PUUPPONEN-PIMIÄ, R., NOHYNEK, L., MEIER, C., KAHKONEN, M., HEINONEN, M., HOPIA, A. and OKSMAN-CALDENTEY, K.M., 2001. Antimicrobial properties of phenolic compounds from berries. Journal of Applied Microbiology, vol. 90, no. 4, pp. 494-507. http:// dx.doi.org/10.1046/j.1365-2672.2001.01271.x. PMid:11309059.

RIOS, J.L., RECIO, M.C. and VILLAR, A., 1988. Screening methods for natural products with antimicrobial activity: a review of the literature. Journal of Ethnopharmacology, vol. 23, no. 2-3, pp. 127-149. http://dx.doi.org/10.1016/0378-8741(88)90001-3. PMid:3057288.

SINGH, G., KUMAR, P. and JOSHI, S.C., 2014. Treatment of dermatophytosis by a new antifungal agent 'apigenin'. Mycoses, vol. 57, no. 8, pp. 497-506. http://dx.doi.org/10.1111/myc.12188. PMid:24708558.
TERRAGNI, L., LASAGNI, A. and ORIANI, A., 1993. Dermatophytes and dermatophytoses in the Milan area between 1970 and 1989. Mycoses, vol. 36, no. 9-10, pp. 313-317. http://dx.doi. org/10.1111/j.1439-0507.1993.tb00773.x. PMid:8015563.

URUMARUDAPPA, S.K.J., TUNGPHATTHONG, C. and SUKRONG, S., 2019. Mitigating the impact of admixtures in thai herbal products. Frontiers in Pharmacology, vol. 10, pp. 1205. http:// dx.doi.org/10.3389/fphar.2019.01205. PMid:31749698.

VIJAYARAGHAVAN, K., RAJKUMAR, J., BUKHARI, S.N., AL-SAYED, B. and SEYED, M.A., 2017. Chromolaena odorata: A neglected weed with a wide spectrum of pharmacological activities (Review). Molecular Medicine Reports, vol. 15, no. 3, pp. 1007-1016. http:// dx.doi.org/10.3892/mmr.2017.6133. PMid:28112383.

WEINSTEIN, A. and BERMAN, B., 2002. Topical treatment of common superficial tinea infections. American Family Physician, vol. 65, no. 10, pp. 2095-2102. PMid:12046779.

ZHAN, P. and LIU, W., 2017. The changing face of dermatophytic infections worldwide. Mycopathologia, vol. 182, no. 1-2, pp. 77-86. http://dx.doi.org/10.1007/s11046-016-0082-8. PMid:27783316.

ZHANG, M.L., WU, M., ZHANG, J.J., IRWIN, D., GU, Y.C. and SHI, Q.W., 2008. Chemical constituents of plants from the genus Eupatorium. Chemistry \& Biodiversity, vol. 5, no. 1, pp. 40-55. http://dx.doi.org/10.1002/cbdv.200890014. PMid:18205126. 